\title{
Nurses' knowledge of the medication management at intensive care units
}

\author{
Wiedza pielęgniarek dotycząca zarządzania lekami na oddziałach intensywnej terapii
}

Jana Heczková1,3, Alan Bulava2,3,4

\begin{abstract}
1Institute of Nursing Theory and Practice, First Faculty of Medicine, Charles University, Czech Republic; 2Department of Cardiology, České Budějovice Hospital, Czech Republic; ${ }^{3}$ Faculty of Health and Social Sciences, Universtiy of South Bohemia in České Budějovice, Czech Republic; ${ }^{4}$ Faculty of Medicine and Dentistry, Palacky University Olomouc, Czech Republic
\end{abstract}

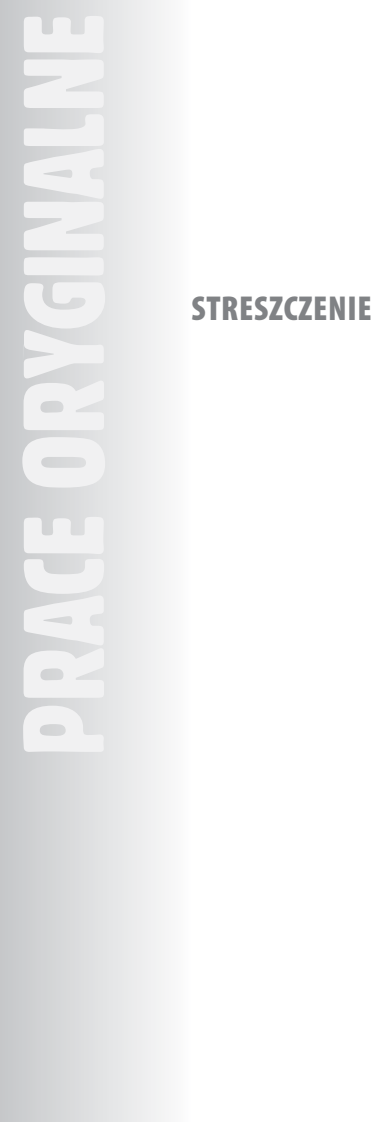

Słowa kluczowe: WIEDZA PIELEZGNIAREK DOTYCZACA ZARZADDZANIA LEKAMI NA OD DZIALACH INTENSYWNEJ TERAPII

Wstęp. Zarządzanie lekami uważane jest za ważny obszar opieki zdrowotnej, który nadzorują różni pracownicy służby zdrowia, w tym pielęgniarki. Te ostatnie zdobywają kompetencje dotyczące administrowania lekami bezpośrednio po ukończeniu studiów. Wiedza ta ma zastosowanie w każdym obszarze opieki zdrowotnej. Nawet na specjalnych oddziałach, takich jak oddziały intensywnej terapii, żadne dodatkowe kwalifikacje ani szkolenia nie są wymagane. Natomiast odpowiednia edukacja uważana jest za ważny czynnik który może być pomocny w redukowaniu ryzyka wystąpienia działań niepożądanych odnoszących się do zarządzania lekami.

Cel pracy. Celem niniejszej pracy było zbadanie w tym obszarze wiedzy studentów pielęgniarstwa pod koniec studiów licencjackich $(n=67)$ oraz studentów specjalizacji 'pielęgniarstwo na intensywnej terapii' pod koniec studiów magisterskich $(n=42)$.

Materiał i metodyka. Wiedza była oceniana przy pomocy pisemnego testu, który odnosił się do zarządzania produktami leczniczymi zwyczajowo podawanymi na oddziałach intensywnej terapii przez wykwalifikowane a także przez wyspecjalizowane pielęgniarki, bez ich rozróżniania. Z punktu widzenia formalnych kompetencji pracowników służby zdrowia, pytania zostały podzielone na trzy kategorie. Wyniki. Średni wskaźnik sukcesu testu wyniósł 53,4\%. Najwyższy zakres wiedzy osiągnęli studenci kończący studia specjalizacyjne z doświadczeniem pracy na oddziale intensywnej terapii, a najniższy, studenci będący przed ukończeniem studiów licencjackich. Wszyscy studenci osiągnęli najwyższy wynik w kategorii ukierunkowanej na działania, w przypadku których odpowiedzialność ponosi lekarz, jednak pielęgniarki są zobowiązane posiadać tę wiedzę i uczestniczyć w działaniach zgodnie z instrukcjami lekarza. Te umiejętności dotyczyły również obszaru farmakologii klinicznej. Z drugiej strony, wszystkie grupy studentów osiągnęły najniższy wynik w kategorii działań, które nie są zlecane przez lekarza, a wymagały zróżnicowanej wiedzy z wielu obszarów.

Wnioski. Praktyka kliniczna jest nie do zastąpienia dla pielęgniarki w procesie edukacji, a także w czasie kształcenia się przez całe życie. Zakres edukacji pielęgniarek dotyczący zarządzania lekami sposobu ich kształcenia, a także proporcji wyspecjalizowanych pielęgniarek w zespole na specjalnych oddziałach, wymagają większej uwagi w zakresie zapewniania w nich bezpiecznej opieki. Przenoszenie niektórych kompetencji oraz obowiązków dotyczących zarządzania lekami, zwłaszcza tymi związanymi z wlewem dożylnym, na mniej wykwalifikowanych pracowników służby zdrowia wydaje się być kontrowersyjne oraz ryzykowne.

ABSTRACT zarządzanie lekami, administrowanie produktów leczniczych, kwalifikacje pielęgniarskie, kształcenie ustawiczne

Introduction. The medicine management is considered an important area of health care, which is ensured by various healthcare professionals including nurses. Nurses gain the competence of medicines administration immediately after graduation. This competence can be applied to any area of healthcare. Even in specialized settings such as intensive care units, any additional qualification e.g. specialized education is not required. On the contrary, appropriate education is considered an important factor that could help to reduce the risk of adverse events related to medication management.

Aim. The aim of this study was to analyse the students' knowledge in this field at the end of nursing studies at bachelor level $(n=67)$ and specialized intensive care nursing studies at master level $(n=42)$.

Methodology. Knowledge was assessed using a written test, which was related to the management of medicinal products administered commonly at intensive care units by qualified nurses as well as nurse specialists without distinction. From the point of view of the formal competencies of healthcare professionals, the questions were divided into three categories.

Results. The mean success rate on the test was $53.4 \%$. The highest range of knowledge was demonstrated by already qualified students at the end of specialised studies with prior work experience in ICU, the lowest by students just before graduation. The highest rating was achieved by all students in the activity-oriented category for which the responsibility lies primarily with the medical doctor, but nurses were expected to have this knowledge and participate at related activities on the basis of 
a physician's order. This knowledge included also the area of clinical pharmacology. On the other hand, the lowest score was achieved by all groups of students in the category of activities that are not treated by the physician's order, and the use of diverse knowledge from different areas was usually necessary.

Conclusions. Clinical practice has an irreplaceable role for nurses in the process of qualifying education as well as lifelong learning. The extent of nursing education in medicine management, the manner of nursing training, as well as the proportion of nursing specialists in the nursing team at specialised workplaces, deserves much greater attention in terms of ensuring safe care in this area. Shifting some competencies and duties in medicine management, especially related to intravenous (IV) therapy, to less qualified healthcare professionals appears to be highly controversial and risky.

Key words: $\quad$ medication management, administering medicinal products, nurses qualification, lifelong learning

\section{INTRODUCTION}

The medication management is considered to be an important, multifaceted and very complex area of health care [1]. Various healthcare workers, sometimes with different, sometimes overlapping, competencies [2, 3], are involved in its provision. Generally speaking, it can be assumed that the physician prescribes, the pharmacist dispenses and the nurse administers the medicines. However, activities related to this area of health care are much more complex and there are also more healthcare professionals involved $[1,4-6]$. It is estimated that nurses activities related to medication management can take up to $40 \%$ of their working hours [7].

Although various clinical settings may require, to some extent, specific knowledge and skills, the nurse is expected to be fully competent to use this knowledge and to perform activities in this area immediately after qualification, even in specialised settings such as intensive care units [1, 8]. Contrary to this expectation, nursing education is criticised for being rather detachment from the clinical practice and superficial. In other cases, it is pointed out that the nursing curriculum has rather insufficient coverage in some areas [9-11], and that nursing theories are not fully relevant to current clinical needs and expected nursing role [12]. Even nurses themselves consider their education and competence in the field of medication management insufficient $[13,14]$. The need to pay more attention to this issue is repeatedly emphasized $[10,15,16]$, as well as the fact that the time spent by the nurse on these activities in real practice is not adequately reflected in the curriculum during the qualifying studies [17]. However, the education in the field of pharmacology and medication management is considered a significant factor $[5,18]$, which could contribute to ensuring safe care in terms of reducing the risk of adverse events and errors [19, 20].

Medication-related errors for a long time have been among the most common preventable adverse events associated with health care [21-23]. Many of these events do not actually lead to patient harm [24, 25], but some do have fatal consequences $[22,24]$. Deaths associated with medication errors are then considered more frequent than, for example, the number of deaths related to car accidents or breast cancer [26]. Although these errors can occur at any time during the entire drug delivery process, e.g. already at the time, when the drug is being prescribed, it is very often the nurse who is blamed for these undesirable events. However, the idea of the need for a systematic approach to ensuring safe care, not merely seeking a guilty individual, has been already gradually promoted [27]. The attention is also paid to the causes and contributing factors of drug errors. These seem to be very heterogeneous [28-30], among others, lack of knowledge, task interruptions, poor documentation [31], the working climate $[6,32]$, but also the workload, shift length or overtime [33] play a part.

A lot of different interventions to reduce drug errors have been tested with limited results [34], but adequate pharmacology education is still considered, not only for nurses, to be an essential requirement to provide safe care $[35,36]$. Although some new teaching and learning methods are already used in nursing education [37], such as simulation $[38,39]$, e-learning [20, 40], formative testing and others $[41,42]$, appropriate content or scope of nursing pharmacology education has not been clearly established. Similarly, it is not yet clear who should be involved in the teaching of different topic related to medication management [43]. Pharmacology is usually taught as a separate subject by a doctor or pharmacologist. However, there is a growing need to link the theoretical knowledge with the clinical practice, which is very complex. Therefore there is also a growing need for wider involvement of qualified nurses in teaching of medication management during the nursing education [37].

\section{METHODOLOGY}

The aim of this study was to analyse the students' pharmacology knowledge at the end of the bachelor's degree programme in nursing and the master's degree programme in intensive care nursing, depending on the level of education and previous work experience. Full-time as well as part-time students of both study programmes provided at the same educational institution were enrolled. Full-time studies for both programs were designed for students without previous work experience although at the master level the students were already qualified nurses. All part-time students of both programs were already qualified nurses with previous work experience, which at the master level was gained during intensive care setting. In total, students were divided into 4 groups depending on their education and work experience (Tab. 2.).

The knowledge was evaluated by a written test at the end of the last semester, during the final exam at the end of clinical placement at the bachelor level and during graduation practical exam at the master level. The test contained a total of 30 multiple choice questions (one or more correct answers were possible). The criteria for evaluation were predetermined in advance. The student 
could get one point for the correct score or zero points for the wrong, incomplete or missing answer for each question. The questions addressed the issue of medicinal products commonly administered at intensive care units by qualified nurses as well as nurses specialised in intensive care without distinction.

Regarding the formal competencies of the physicians and nurses in pharmacotherapy, the questions fell into three different categories (Tab. 1.). Category A included questions related to the activities and procedures for which the physician is formally responsible, however the knowledge of a nurse is desirable and expected, since the nurse participates in these activities on the basis of a physician's order. Category B concerned activities where the responsibility is shared, to a certain extent, by a nurse and a doctor. These activities are not always treated by the doctor's order in full extent, therefore the nurse is expected to know this procedure even without the order. Category $\mathrm{C}$ included areas and activities of medicines management, which are often provided by a nurse and usually are not treated by the doctor's order, but can be ensured by hospital policy or based on certain unwritten rules of the workplace. Each of the categories contained 10 questions.

Tab. 1. Types and topics of questions for each category.

\begin{tabular}{|c|c|c|}
\hline Category A & Category B & Category C \\
\hline Doctor's Responsibility & Shared Responsibility & Nurse's Responsibility \\
\hline $\begin{array}{l}\text { 1) Adjusting the rate } \\
\text { of insulin administrated } \\
\text { by IV according to the } \\
\text { glycaemia } \\
\text { 2) Adjusting the rate of } \\
\text { potassium administrated } \\
\text { by IV according to its } \\
\text { serum concentration } \\
\text { 3) Adjusting the dose of } \\
\text { potassium administered } \\
\text { orally according to its } \\
\text { serum concentration } \\
\text { 4) Adjusting the rate } \\
\text { of norepinephrine } \\
\text { administered by IV } \\
\text { according to the blood } \\
\text { pressure values } \\
\text { 5) Adjusting the rate } \\
\text { of antihypertensive } \\
\text { agents administered by } \\
\text { IV according to the blood } \\
\text { pressure values } \\
\text { 6) Adjusting the rate } \\
\text { of antiarrhythmic agent } \\
\text { administered by IV } \\
\text { according to heart rate } \\
\text { and rhythm } \\
\text { 7) Recommended } \\
\text { drug therapy in case of } \\
\text { hyperkalaemia } \\
\text { 8) Recommended drug } \\
\text { therapy in case of cardiac } \\
\text { arrest } \\
\text { 9) Recommended } \\
\text { drug therapy in case of } \\
\text { hypoglycaemia } \\
\text { 10) Generic substitution }\end{array}$ & $\begin{array}{l}\text { 1) Signs of } \\
\text { hyperkalaemia } \\
\text { 2) Signs of } \\
\text { hypokalaemia } \\
\text { 3) Warfarin and } \\
\text { Amiodarone interactions } \\
\text { 4) Administering } \\
\text { adrenaline during } \\
\text { ventricular fibrillation } \\
\text { 5) Specifics of } \\
\text { catecholamine's } \\
\text { administration } \\
\text { 6) Specifics of } \\
\text { antiarrhythmic agents } \\
\text { administration } \\
\text { 7) Specifics of medicines } \\
\text { with high osmolality } \\
\text { administration } \\
\text { 8) Diluents for IV } \\
\text { administration of } \\
\text { antiarrhythmic agents } \\
\text { 9) Diluents for IV } \\
\text { administration of } \\
\text { antibiotics } \\
\text { 10) Diluents for IV } \\
\text { administration of insulin }\end{array}$ & $\begin{array}{l}\text { 1) Side effects } \\
\text { of Fentanyl IV } \\
\text { administration } \\
\text { 2) Side effects } \\
\text { of magnesium IV } \\
\text { administration } \\
\text { 3) Calculating amount } \\
\text { of heparin } \\
\text { 4) Concentration of } \\
\text { adrenaline } \\
\text { 5) Tubing replacement } \\
\text { for Propofol } \\
\text { administration } \\
\text { 6) Cessation of } \\
\text { catecholamine } \\
\text { administration } \\
\text { 7) Medicinal products } \\
\text { for mouth care } \\
\text { 8) Catecholamine and } \\
\text { diuretics interactions } \\
\text { 9) Antibiotics } \\
\text { interactions } \\
\text { 10) Antihypertensive } \\
\text { agents interactions }\end{array}$ \\
\hline
\end{tabular}

MS Excel 2017 and SW Statistica 12.0 were used to analyse the obtained data. The scores for the whole test as well as for the different categories of questions were analysed. In order to compare the students' knowledge in three categories of questions, the nonparametric Friedman's ANOVA and Kendall coefficient of correspondence were used. To compare the knowledge of different student groups, a nonparametric Kruskal-Wallis test followed by a multiple comparison of $\mathrm{p}$ values were used.

\section{RESULTS}

A total of 109 students were included in the study, 67 bachelor and 42 master students. The average score in the test for all students was 16 out of 30 points (53.4\%). The overall success rate was $45.5 \%$ for the bachelor students and $66 \%$ for the master students. In a more detailed analysis, the lowest success rate was observed in students of the bachelor full-time studies and the highest one in the students of master part-time studies (Table 2.). None of the students achieved full 30 points $(100 \%)$ in the test, but all questions were answered correctly by at least some students, and no question was answered correctly by all students.

Tab. 2. Total test results.

\begin{tabular}{|l|c|c|c|c|}
\hline \multirow{2}{*}{$\begin{array}{c}\text { Study } \\
\text { programme }\end{array}$} & \multicolumn{2}{|c|}{ Bachelor's students } & \multicolumn{2}{c|}{ Master's students } \\
\cline { 2 - 5 } & Full-time & Part-time & Full-time & Part-time \\
\hline $\mathrm{n}$ & 19 & 48 & 13 & 29 \\
\hline $\begin{array}{l}\text { Previous } \\
\text { qualification }\end{array}$ & None & General nurse & General nurse & General nurse \\
\hline $\begin{array}{l}\text { Previous clinical } \\
\text { practice }\end{array}$ & No & $\begin{array}{c}\text { Yes, different } \\
\text { settings }\end{array}$ & No & Yes, ICU \\
\hline Success rate & $33.2 \%$ & $50.4 \%$ & $61.3 \%$ & $68.2 \%$ \\
\hline Average score & 9.9 & 15.1 & 18.4 & 20.4 \\
\hline Median & 9 & 15.5 & 18 & 21 \\
\hline Mode & Multiple & Multiple & 18 & 21 \\
\hline Minimum & 4 & 5 & 17 & 6 \\
\hline Maximum & 15 & 21 & 20 & 26 \\
\hline Variance & 10.9 & 13.1 & 0.6 & 20.3 \\
\hline $\begin{array}{l}\text { Standard } \\
\text { deviation }\end{array}$ & 3.3 & 3.6 & 0.8 & 4.5 \\
\hline
\end{tabular}

Eight questions were answered correctly by more than $4 / 5$ of the students. Five of those questions belonged to category A and three to category B. On the other hand, more than 4/5 students did not know the correct answer for three other questions, which all fall into category C.

The most extensive knowledge was demonstrated by students in the field related to adjusting the rate of administering infusion medication according to its effect (category A). The most problematic area was the mutual interactions of medicines administered intravenously at the same time. However, these questions were not directed to the description of good practice, but more to the rationale behind the common practice (category $\mathrm{C}$ ).

Success rates were also analysed for each category of questions A, B and C. Each category included 10 questions, 
so students could always get a maximum of 10 points in a category. In general, the students achieved the highest average score of 7.1 out of 10 possible points in category A, and then 5.9 in category B. The lowest average score of 3.0 was then reached in category C. The difference in the average number of successfully answered questions in categories A, B, C was statistically significant $(\mathrm{p}<0.001)$.

The results achieved in each category by particular student group were analysed as well. The most extensive knowledge was demonstrated by full-time students at master level in category A. On the other hand, category C was the most problematic, where the best knowledge had the part-time students at master level. The lowest score was achieved in all categories by full-time students of bachelor study (Fig. 1.).

The difference among the average number of successfully answered questions and the score achieved in categories A, B and C was statistically significant, not only in the overall evaluation, but also when the results in these categories were compared in each student group (Tab. 3.).

Tab. 3. Test results by categories.

\begin{tabular}{|l|c|c|c|c|c|c|c|c|}
\hline \multirow{2}{*}{$\begin{array}{c}\text { Study } \\
\text { programme }\end{array}$} & \multicolumn{4}{|c|}{ Bachelor's students } & \multicolumn{4}{c|}{ Master's students } \\
\cline { 2 - 9 } & \multicolumn{2}{|c|}{ Full-time } & \multicolumn{2}{c|}{ Part-time } & \multicolumn{2}{c|}{ Full-time } & \multicolumn{2}{c|}{ Part-time } \\
\hline & $\begin{array}{c}\text { Average } \\
\text { score }\end{array}$ & $\begin{array}{c}\text { Standard } \\
\text { deviation }\end{array}$ & $\begin{array}{c}\text { Average } \\
\text { score }\end{array}$ & $\begin{array}{c}\text { Standard } \\
\text { deviation }\end{array}$ & $\begin{array}{c}\text { Average } \\
\text { score }\end{array}$ & $\begin{array}{c}\text { Standard } \\
\text { deviation }\end{array}$ & $\begin{array}{c}\text { Average } \\
\text { score }\end{array}$ & $\begin{array}{c}\text { Standard } \\
\text { deviation }\end{array}$ \\
\hline Category A & 4.84 & 2.77 & 6.81 & 1.96 & 9.15 & 0.69 & 8.17 & 1.36 \\
\hline Category B & 4.00 & 1.35 & 5.71 & 1.41 & 5.69 & 0.85 & 7.48 & 2.20 \\
\hline Category C & 1.11 & 1.49 & 2.6 & 1.44 & 3.54 & 0.66 & 4.79 & 2.04 \\
\hline & \multicolumn{3}{|c|}{$\mathrm{p}<0.001$} & \multicolumn{3}{c|}{$\mathrm{p}<0.001$} & \multicolumn{3}{c|}{$\mathrm{p}<0.001$} & \multicolumn{2}{c|}{$\mathrm{p}<0.001$} \\
\hline
\end{tabular}

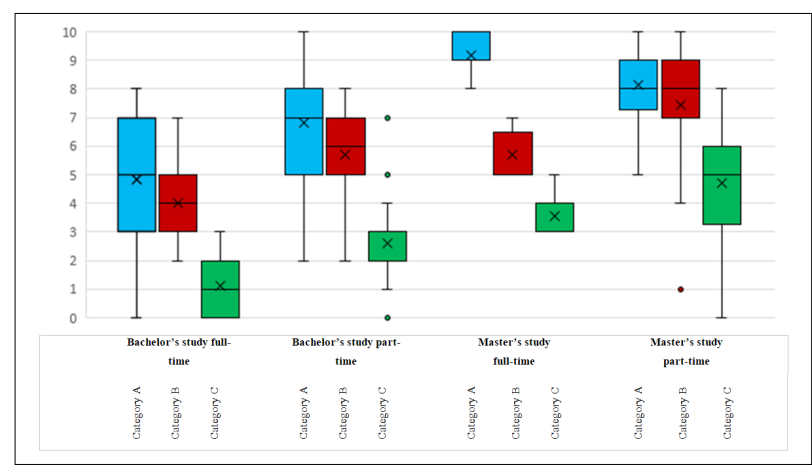

Fig 1. Test results by categories.

When student groups' results were compared, the difference in achieved overall scores was again statistically significant, as well as for each category of questions (Tab. 4.).

Consequently, multiple comparisons for all student groups were made. The most statistically significant differences in the comparison of student groups were found during analysis of overall scores in whole test and scores in category A (Tab. 4.).

\section{DISCUSSION}

Competence to administer medicinal products on the basis of a physician's prescription is acquired by a nurse in the Czech Republic immediately after the successful completion of the qualifying studies. This competence can be also applied in a highly specialised setting, such as intensive care unit [8]. Although the knowledge test was designed so that all questions could be answered by all groups of students without dependence on the already completed qualification or previous work experience in clinical practice, the analysis of the results demonstrated the wider knowledge of the already qualified part-time students compared to the full-time students at the bachelor level. These results were consistent with the conclusions of previous studies comparing students' knowledge at the end of studies and already qualified nurses in practice [11, $13,44]$. It can be assumed, therefore, that clinical practice plays an irreplaceable part in the learning process during qualifying education and that this process continues, to a significant extent, after graduation.

Similarly, better results were achieved by intensive care nursing students compared to the corresponding bachelor study, although the competence to administer medicines in the intensive care setting is not conditional upon any additional education when obtaining a general nurse qualification. A significant difference in the knowledge was also seen not only in the groups with different education level were compared, but also in the groups of students with previous work experience were compared, that is the part-time bachelor students

Tab. 4. Multiple comparison of $p$ values.

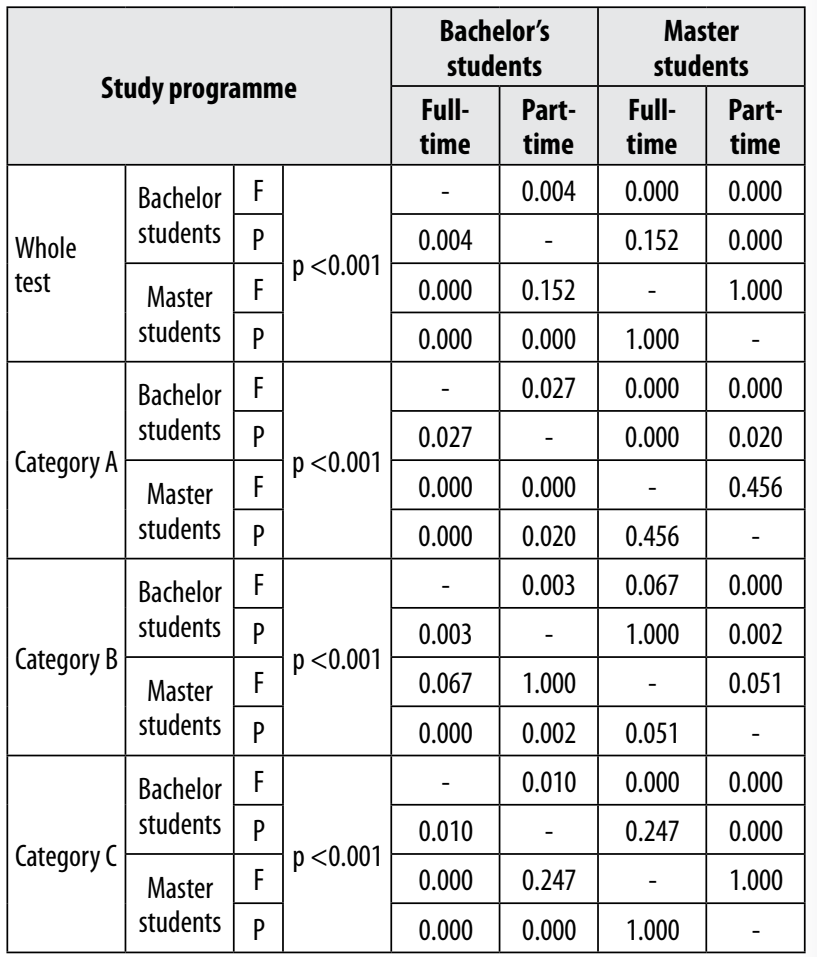


with previous work experience in various settings and the part-time master students with specific work experience at intensive care. Here again, the differences in overall results were favouring master students with experience at intensive care units. Work experience in this type of clinical setting should therefore be considered a factor that plays an important role in lifelong learning. To ensure safe care in this area, the orientation process of newly-graduated nurses seems essential as well as the orientation process for nurses new in intensive care units.

Some previous works also demonstrated a different range of knowledge in evaluating the different aspects related to medication management $[9,12]$. Similarly, here the analysis of test results showed significant differences in the knowledge related to the different categories of questions. The highest scores were achieved by all student groups in the category most relevant to the formal medical doctor's competencies and the knowledge related to clinical pharmacology.

The lowest scores were achieved, again, in all student groups, in the category, which was mainly connected with activities ensured by the nurse, but where, except for pharmacology, also other knowledge from different areas needs to be applied at the same time, e.g. infection control, unusual calculation, evidence based nursing, nursing procedures etc. In this respect, it is necessary to consider the discussion concerning the adequate forms of teaching or the way in which theoretical knowledge is implemented in practical training, as well as wider involvement of nurses in teaching medication management as fully justified [37].

Last but not least, it must be emphasised that the overall score achieved in the knowledge test was lower, especially for the bachelor students. Although the results of the knowledge test do not predict the risk of errors in real clinical practice [45-47] and the systemic approach to addressing the risks and already occurred adverse events has to be considered as crucial [48], it seems that medicines management in nursing practice would deserve more attention and support than so far.

On the contrary, in relation to the results of this study, shifting some competencies and duties in medicine management in acute setting, especially related to IV therapy, to less qualified healthcare professionals, such as healthcare assistants, appears to be highly controversial and risky. Although some activities related to this area of health care are reported to be delegated to less qualified healthcare staff in social and care services, it is usually the case of locally applied or oral, but not IV medicines $[49,50]$. Caution should be exerted for higher-risk medicines [51], as relationship between the increasing number of adverse drug events and the lower education of those providing the care has already been documented [52], as well as the relationship between the level of education among nursing staff and health care outcomes [53].

\section{CONCLUSIONS}

Clinical practice has an irreplaceable role for nurses during the process of qualifying education as well as lifelong learning. Practice in the clinical environment plays an irreplaceable part in nursing learning process during both qualifying and postgraduate education. Although the quality of education of those involved in the medication management represents only one of many factors that may have an impact on reducing the risk of adverse events and providing safe care in this area, the scope and mode of nursing education should deserve more attention.

From the point of view of the formal competencies of nurses in this area, there is no difference in the range of activities performed by qualified nurse and nurse specialist, even in specialised settings. In the view of this study results, sufficient representation of nursing specialists in the nursing team seems highly desirable, although the impact of their representation on the occurrence of undesirable events at intensive care units will require further research. Proposed shift of some competencies and duties in medicine management, especially related to IV therapy, to less qualified healthcare professionals appears to be highly controversial and risky especially if the facility is dependent on limited human resources.

\section{REFERENCES}

1. Sulosaari V, Suhonen R, Leino-Kilpi H. An integrative review of the literature on registered nurses' medication competence. Journal of Clinical Nursing. 2010; 20(3/4): 464-478

2. Bell HT, Granas AG, Enmarker I, et al. Nurses' and pharmacists' learning experiences from participating in interprofessional medication reviews for elderly in primary health care - a qualitative study. BMC Family Practice. 2017; 1(18): 30.

3. Heczkova J, Bulava A. The role of nurses in medication management in the Czech Republic: A narrative literature review. Ošetrovatelstvo: teoria, výskum, vzdelavanie. 2016; 6 .

4. Sulosaari V, Erkko $P$, Walta L. Medication competence requirements of a graduating registered nurse. Turku University of Applied Sciences, 2010.

5. Dilles T, Vander Stichele R, Van Rompaey B, et al. Nurses' practices in pharmacotherapy and their association with educational level. Journal of Advanced Nursing. 2010; 5(66): 1072-1079.

6. Orbæk J, Gaard M, Fabricius P, et al. Patient safety and technology-driven medication - A qualitative study on how graduate nursing students navigate through complex medication administration. Nurse Education in Practice. 2015; 3(15): 203-211.

7. Leufer T, Cleary-Holdforth J. Let's do no harm: Medication errors in nursing: Part 1. Nurse Education in Practice. 2013; 3(13): 213-216.

8. Czech Republic. Vyhláška č. 55/2011 Sb. o činnostech zdravotnických pracovníků.

9. Lim AG, Honey M. New Zealand newly graduated nurses medication management: results of a survey. Nurse Education in Practice. 2014; 6(14): 660-665.

10. Fleming S, Brady A-M, Malone A-M. An evaluation of the drug calculation skills of registered nurses. Nurse Education in Practice. 2014; 1(14): 55-61.

11. Simonsen BO, Daehlin GK, Johansson I, et al. Differences in medication knowledge and risk of errors between graduating nursing students and working registered nurses: comparative study. BMC Health Services Research. 2014; 14: 580.

12. Sneck S, Saarnio R, Isola A, et al. Medication competency of nurses according to theoretical and drug calculation online exams: A descriptive correlational study. Nurse Education Today. 2016; 36: 195.

13. Manias $E$, Bullock $S$. The educational preparation of undergraduate nursing students in pharmacology: clinical nurses' perceptions and experiences of graduate nurses' medication knowledge. International Journal of Nursing Studies. 2002, 8(39): 773784.

14. Manias E, Bullock S. The educational preparation of undergraduate nursing students in pharmacology: Perceptions and experiences of lecturers and students. International Journal of Nursing Studies. 2002; 7(39): 757-769.

15. Dilles T, Vander Stichele RR, Van Bortel L, et al. Nursing students' pharmacological knowledge and calculation skills: Ready for practice? Nurse Education Today. 2011; 5(31): 499-505.

16. Bagnasco A, Galaverna L, Aleo G, et al. Mathematical calculation skills required for drug administration in undergraduate nursing students to ensure patient safety: A descriptive study: Drug calculation skills in nursing students. Nurse Education in Practice. 2016; 1(16): 33-39. 
17. Morrison-Griffiths S, Snowden MA, Pirmohamed M. Pre-registration nurse education in pharmacology: is it adequate for the roles that nurses are expected to fulfil? Nurse Education Today. 2002; (6)22: 447-456.

18. Cleary-Holdforth J, Leufer T. The strategic role of education in the prevention of medication errors in nursing: Part 2. Nurse Education in Practice. 2013; 3(13): $217-$ 220.

19. Page K, McKinney AA. Addressing medication errors - The role of undergraduate nurse education. Nurse Education Today. 2007; 3(27): 219-224.

20. Mettiäinen $S$, Luojus $K$, Salminen $S$, et al. Web course on medication administration strengthens nursing students' competence prior to graduation. Nurse Education in Practice. 2014; 4(14): 368-373.

21. Manno MS. Preventing adverse drug event. Nursing. 2006; 3(36): 56-62.

22. Baker GR, Norton PG, Flintoft V, et al. The Canadian Adverse Events Study: the incidence of adverse events among hospital patients in Canada. Canadian Medical Association Journal. 2004; 11(170): 1678-1686.

23. Deans C. Medication errors and professional practice of registered nurses. Collegian. 2005;12(1): 29-33.

24. Johnson M, Tran DT, Young H. Developing risk management behaviours for nurses through medication incident analysis. International Journal of Nursing Practice. 2011; 6(17): 548-555.

25. Berdot S, Gillaizeau F, Caruba T, et al. Drug administration errors in hospital inpatients: a systematic review. Plos One. 2013; 6 (8): e68856-e68856.

26. Kohn LT, Corrigan JM, Donaldson MS, eds. To Err Is Human: Building a Safer Health System. National Academies Press; 2000.

27. Wright $K$. The role of nurses in medicine administration errors. Nursing Standard. 2013; 27(44): 35-40.

28. Armitage $G$, Knapman H. Adverse events in drug administration: a literature review. Journal of Nursing Management. 2003; 2 (11): 130-140.

29. Drach-Zahavy A, Somech A, Admi H, et al. (How) do we learn from errors? A prospective study of the link between the ward's learning practices and medication administration errors. International Journal of Nursing Studies. 2014; 3 (51): 448 457.

30. Hemingway S, McCann T, Baxter H, et al. The perceptions of nurses towards barriers to the safe administration of medicines in mental health settings. International Journal of Nursing Practice. 2015; 6 (21): 733-740.

31. Slade S. Medication Errors: Contriuting Factors. The Joanna Briggs Institute, 2013.

32. Sahay A, Hutchinson M, East L. Exploring the influence of workplace supports and relationships on safe medication practice: A pilot study of Australian graduate nurses. Nurse Education Today. 2015; 5(35): e21-e26.

33. Parry AM, Barriball KL, While AE. Factors contributing to Registered Nurse medication administration error: A narrative review. International Journal of Nursing Studies. 2015; 1(52): 403-420.

34. Manias $E$, Williams $A$, Liew $D$. Interventions to reduce medication errors in adult intensive care: a systematic review. British Journal of Clinical Pharmacology. 2012; 3(74): 411-423.

35. Adhikari $R$, Tocher J, Smith $P$, et al. A multi-disciplinary approach to medication safety and the implication for nursing education and practice. Nurse Education Today. 2014; 2 (34): 185-190.

36. Leape LL, Berwick D, Clancy C, et al. Transforming healthcare: A safety imperative. Quality and Safety in Health Care. 2009; 6(18): 424-428.

37. Fothergill Bourbonnais F, Caswell W. Teaching successful medication administration today: more than just knowing your ,rights'. Nurse Education in Practice. 2014; 4(14): 391-395.

38. Campbell CA. Impact of simulation on safe medication practice with diploma/ADN students. Teaching and Learning in Nursing. 2013; 4(8): 147-156.

39. Ferguson A, Delaney B, Hardy $G$. Teaching medication administration through innovative simulation. Teaching and Learning in Nursing. 2014; 2(9): 64-68.

40. Hewitt J, Tower M, Latimer $S$. An education intervention to improve nursing students' understanding of medication safety. Nurse Education in Practice. 2015; 1(15): 17-21.

41. Hayes C, Power T, Davidson PM, et al. Nurse interrupted: Development of a realistic medication administration simulation for undergraduate nurses. Nurse Education Today. 2015; 9(35): 981-986.

42. Grugnetti AM, Bagnasco A, Rosa F, et al. Effectiveness of a Clinical Skills Workshop for drug-dosage calculation in a nursing program. Nurse Education Today. 2014; 4(34): 619-624.

43. Latter $S$, Rycroft-Malone J, Yerrell $P$, et al. Evaluating educational preparation for a health education role in practice: the case of medication education. Journal of Advanced Nursing. 2000; 5(32): 1282-1290.

44. Honey M, Lim AG. Application of pharmacology knowledge in medication management by final year undergraduate nursing students. Contemporary Nurse. 2008; 1(30): 12-19.
45. Wright K. A written assessment is an invalid test of numeracy skills. Britiah Journal of Nursing. 2007; 16(13)

46. Wright K. Drug calculations part 1: a critique of the formula used by nurses. Nursing Standard. 2008; 22(36): 42-44.

47. Wright K. Drug calculations part 2: alternative strategies to the formula. Nursing Standard. 2008; 22(37): 42-44.

48. Wang $\mathrm{H}-\mathrm{f}$, Jin J-f, Feng $\mathrm{X}$-q, et al. Quality improvements in decreasing medication administration errors made by nursing staff in an academic medical center hospital: a trend analysis during the journey to Joint Commission International accreditation and in the postaccreditation era. Therapeutics \& Clinical Risk Management. 2015; 11: 393-406.

49. Gransjon Craftman A, Hammar LM, von Strauss E, et al. Unlicensed personnel administering medications to older persons living at home: A challenge for social and care services. International Journal of Older People Nursing, 2015; 3 (10): $201-$ 210.

50. Ryder PT, Joseph M, Zuckerman M, et al. Administrators' Perceptions of Medication Management in Assisted Living Facilities: Results from Focus Groups. The Consultant Pharmacist. 2009; 7 (24): 513-523.

51. Young HM, Gray SL, McCormick WC, et al. Types, prevalence, and potential clinical significance of medication administration errors in assisted living. Journal of the American Geriatrics Society. 2008; 7(56): 1199-1205.

52. Chang Y-K, Mark BA. Antecedents of severe and nonsevere medication errors. Journal of Nursing Scholarship. 2009; 1(41): 70-78.

53. Aiken L. Baccalaureate Nurses and Hospital Outcomes: More Evidence. Med Care. 2014; 10(52): 861-863.

Manuscript received: 14.01 .2018

Manuscript accepted: 23.01.2018 